DE DE GRUYTER

OPEN

DOI 10.1515/pesd-2016-0021

PESD, VOL. 10, no. 2, 2016

\title{
THE RISK OF EXCESS RAINFALL OVER THE REPUBLIC OF MOLDOVA TERRITORY
}

\author{
Nedealcov Maria ${ }^{1}$, Domenco Rodion $^{2}$, Sîrbu Rodica ${ }^{1}$
}

Key words: excess rainfall, season, frequency

\begin{abstract}
In this study we aim to highlight the risk of excess rainfall over the Republic of Moldova territory, analyzing the magnitude and frequency of maximum diurnal, seasonal and annual rainfall. The research is based on data from three meteorological stations (Briceni, Chisinau and Cahul) for the period 1950-2015. The maximum rainfall analysis from the three stations in the republic indicates a decrease of maximum annual averages from north toward south. Regarding the frequency of rainfall excess that reach and exceed the threshold of $50 \mathrm{~mm}$ - stands south of the country, being influenced by Mediterranean Cyclones. In annual aspect, for all analyzed stations, the highest frequency rank the classes reaching values of 500-600 $\mathrm{mm}$, each station having its peculiarities.
\end{abstract}

\section{Introduction}

At present, the evolution of atmospheric circulation influences the maximum rainfall regime, and requires the study related to excess rainfall manifested in the regional aspect. The maximum rainfall diurnal multiannual manifestation have a tendency to increase their amounts over the most territory of Republic of Moldova, in the most cases causing the triggering to flooding events.

Atmospheric precipitation being a climate element that is characterized firstly, by discontinuity and large variations in time and space. Intensity, extension and position of baric centers determine the forms and types of atmospheric circulation, affecting the genesis weather and the origin of the thermal and precipitation surplus.

\footnotetext{
1 Institute of Ecology and Geography of ASM, Chisinau, Republic of Moldova, marianedealcov@yahoo.com,sirburada@gmail.com

${ }^{2}$ University of the Academy of Sciences of Moldova, Chisinau, Republic of Moldova, rodion.domenco@gmail.com
} 


\section{Data and methods}

In the present study data from three stations were considered: Briceni - for north of the republic; Chisinau - center of the country and Cahul - south of the country. Data for a period of 66 years (1950-2015) were analyzed. Using Statgraphics Centurion for statistical analysis frequencies and probabilities manifestation of maximum precipitation were determiat.

\section{Results}

In temporal aspect as can be observed from Table 1, excess rainfall attested lately were recorded in 2005, 2008, 2010 and 2013. At Briceni station, the highest amount of precipitation was attested in $2010 ; 952.1 \mathrm{~mm}$, at Chisinau station the same year ranks as second among the most rainy years, with $735 \mathrm{~mm}$ of rainfall, and at Cahul weather station - 2010 ranks as theeighth position; $698.4 \mathrm{~mm}$. If in the north of the country the most humid year was 2010, in central and southern republic the 1966 year is the one that had the greatest amounts of precipitation $744 \mathrm{~mm}$, respectively $818 \mathrm{~mm}$.

Table 1. Rankings years with annual precipitation excess (1950-2015)

\begin{tabular}{cccccc}
\hline \multicolumn{3}{c}{ Briceni } & \multicolumn{2}{c}{ Chișinău } & \multicolumn{2}{c}{ Cahul } \\
\hline$\underline{\mathbf{2 0 1 0}}$ & $\mathbf{9 5 2 , 1}$ & 1966 & 774 & 1966 & 818 \\
1998 & 892 & $\underline{\mathbf{2 0 1 0}}$ & $\underline{\mathbf{7 3 5}}$ & 1997 & 813 \\
1996 & 834 & 1955 & 721 & 1972 & 740 \\
1969 & 802 & 1980 & 712 & 1974 & 721 \\
$\mathbf{2 0 0 5}$ & $\underline{\mathbf{8 0 0}}$ & 1996 & 711 & 1979 & 721 \\
$\mathbf{1 9 8 1}$ & $\mathbf{7 9 6}$ & 1995 & 702 & 1958 & 720 \\
$\underline{\mathbf{2 0 0 8}}$ & $\mathbf{7 7 3}$ & 1979 & 684 & $\underline{\mathbf{2 0 1 3}}$ & $\underline{\mathbf{7 1 7 , 2}}$ \\
1978 & 765 & 1991 & 673 & $\underline{\mathbf{2 0 1 0}}$ & $\underline{\mathbf{6 9 8 , 4}}$ \\
1955 & 759 & 1970 & 672 & $\mathbf{1 9 9 9}$ & 674 \\
1970 & 747 & 1984 & 669 & 1969 & 661 \\
\hline
\end{tabular}

During the winter (Table 2) in the last period, the 2005, 2007, 2010, 2012 were the years with the highest precipitation amounts.

Thus, for all three weather stations' data taken in the study, years 2010, 2012 were ranked as second and third places in the top years with excess rainfall. Absolute maximum, however, belong to the '60s $(1963,1966,1969)$. At the same time, we find that during the cold season of the year the highest values of rainfall are registered in the south, which is largely determined by the influence of Mediterranean cyclones.

During the spring season, in the north of the country, the surplus amount of precipitation for the past 15 years are registered in 2005, 2006 and 2008 (Table 3). 
In the central part of the country, 2006 ranks second in the top years with rainfall excess. For meteorological station Cahul - 2014 ranks among the first 10 years with rainfall surplus. We note that in the north the absolute values of rainfall were recorded in $1962(246 \mathrm{~mm})$, in the center $1984(265 \mathrm{~mm})$ and for the south of the country in $1991(283 \mathrm{~mm})$.

Table 2. The rankings years with seasonal precipitation excess (winter)

\begin{tabular}{llllll}
\hline \multicolumn{2}{c}{ Briceni } & \multicolumn{2}{c}{ Chișinău } & \multicolumn{2}{c}{ Cahul } \\
\hline 1966 & 219 & 1963 & 247 & 1966 & 270 \\
$\frac{\mathbf{2 0 1 2}}{\mathbf{2 0 1 0}}$ & $\underline{\mathbf{1 9 5}}$ & $\underline{\mathbf{2 0 1 0}}$ & $\underline{\mathbf{2 3 1}}$ & 1969 & 268 \\
$\mathbf{1 9 9 6}$ & $\underline{\mathbf{1 7 8}}$ & 1966 & $\frac{\mathbf{2 0 1 2}}{195}$ & $\underline{\mathbf{2 4 4}}$ \\
1963 & 176 & 1969 & 203 & 1956 & 211 \\
1970 & 175 & $\underline{\mathbf{2 0 1 2}}$ & $\underline{\mathbf{1 7 4}}$ & 1965 & 169 \\
1969 & 171 & $\underline{\mathbf{2 0 0 7}}$ & $\underline{\mathbf{1 6 8}}$ & 1953 & 152 \\
1953 & 168 & $\underline{1984}$ & $\mathbf{1 6 5}$ & 1952 & 149 \\
$\frac{\mathbf{2 0 0 5}}{1952}$ & $\underline{\mathbf{1 6 6}}$ & 1999 & 162 & 1986 & 148 \\
\hline
\end{tabular}

Table 3. Rankings the years with seasonal precipitation excess (spring) (1950-2015)

\begin{tabular}{llllll}
\hline \multicolumn{2}{c}{ Briceni } & \multicolumn{2}{c}{ Chișinău } & \multicolumn{2}{c}{ Cahul } \\
\hline 1962 & 246 & 1984 & 265 & 1991 & 283 \\
$\frac{\mathbf{2 0 0 6}}{\underline{\mathbf{2 0 0 5}}}$ & $\underline{\mathbf{2 3 3}}$ & $\underline{\mathbf{2 0 0 6}}$ & $\underline{\mathbf{2 2 3}}$ & 1984 & 238 \\
$\mathbf{1 9 7 8}$ & $\underline{\mathbf{2 2 6}}$ & 1988 & 204 & 1978 & 238 \\
1970 & 221 & 1991 & 204 & 1993 & 225 \\
1981 & 211 & 1993 & 203 & 1988 & 213 \\
$\underline{\mathbf{2 0 0 8}}$ & $\underline{\mathbf{2 0 8}}$ & 1979 & 199 & 1966 & 207 \\
1971 & 203 & 1962 & 185 & $\underline{\mathbf{2 0 1 4}}$ & $\underline{\mathbf{2 0 1}}$ \\
1995 & 201 & 1980 & 171 & 1971 & 190 \\
1965 & 190 & 1978 & 166 & 1958 & 177 \\
\hline
\end{tabular}

During the summer season is summed the highest amount of precipitation with a significant share of the total annual amount of precipitation. Analyzing the maximum amount of rainfall in this season (Table 4) shows that in the period 1950 - 2015 the highest values were recorded in 1997 - in the south of the republic (447 $\mathrm{mm})$; in 2010 - for the north of the country $(435 \mathrm{~mm})$ and 1983 - in center of the country $(349 \mathrm{~mm})$. At the same time we note that during 2000-2015, among the wettest summers stands out 2002 for central and southern of the republic; 2005 the center and north of the country; 2010 - for the north and south of the country. 
Table 4. Rankings the years with seasonal precipitation excess (summer)

(1950-2015)

\begin{tabular}{llllll}
\hline \multicolumn{2}{c}{ Briceni } & \multicolumn{2}{c}{ Chișinău } & \multicolumn{2}{c}{ Cahul } \\
\hline$\frac{\mathbf{2 0 1 0}}{1969}$ & $\underline{\mathbf{4 3 5}}$ & 1983 & 349 & 1997 & 447 \\
$\mathbf{2 0 0 3}$ & $\underline{\mathbf{3 9 9}}$ & 1955 & 324 & 1983 & 383 \\
$\mathbf{1 9 9 8}$ & $\mathbf{3 9 2}$ & 1991 & 307 & 1972 & 362 \\
1972 & 362 & 1980 & 307 & 1999 & 314 \\
1988 & 339 & 1952 & 298 & 1974 & 304 \\
1955 & 334 & 1954 & 278 & $\underline{\mathbf{2 0 1 0}}$ & $\underline{\mathbf{2 9 0 2}}$ \\
$\frac{\mathbf{2 0 0 5}}{\mathbf{2 0 0 6}}$ & $\underline{\mathbf{3 2 9}}$ & $\underline{\mathbf{2 0 0 5}}$ & $\underline{\mathbf{2 7 6}}$ & $\mathbf{\mathbf { 2 9 0 }}$ \\
$\mathbf{1 9 8 9}$ & $\underline{\mathbf{2 0 0 2}}$ & $\underline{\mathbf{2 7 5}}$ & 1958 & 289 \\
\hline
\end{tabular}

In the autumn, seasonal maximum amounts of rainfall decrease, compared to the summer season, thus maximum values are below $351 \mathrm{~mm}$; registered in 2013, in south of the country, at meteorological station Cahul. In the north and center of the country, the wettest autumn in the period under review it was in 1996, when $274 \mathrm{~mm}$ and $324 \mathrm{~mm}$ respectively were registered. In the top of autumns' excess rainfall from the last 15 years, the 2001 year is highlighted (the third position in the north and center of the country and fourth in the south).

Table 5. Rankings the years with seasonal precipitation excess (autumn)

\begin{tabular}{llllll}
\hline \multicolumn{2}{c}{ Briceni } & \multicolumn{2}{c}{ Chișinău } & \multicolumn{2}{c}{ Cahul } \\
\hline 1996 & 274 & 1996 & 324 & $\underline{\mathbf{2 0 1 3}}$ & $\underline{\underline{\mathbf{3 5 1}}}$ \\
1998 & 273 & 1998 & 295 & 1974 & 247 \\
$\underline{\mathbf{2 0 0 1}}$ & $\underline{\mathbf{2 3 5}}$ & $\underline{\mathbf{2 0 0 1}}$ & $\underline{\mathbf{2 4 3}}$ & 1972 & 247 \\
1960 & 219 & 1976 & 224 & $\underline{\mathbf{2 0 0 1}}$ & $\underline{\mathbf{2 4 7}}$ \\
1974 & 216 & 1981 & 221 & 1952 & 233 \\
1968 & 213 & 1972 & 215 & 1998 & 218 \\
1976 & 212 & $\underline{\mathbf{2 0 0 2}}$ & $\underline{\mathbf{2 0 7}}$ & 1964 & 216 \\
1955 & 197 & $\underline{1995}$ & 207 & 1962 & 210 \\
1964 & 197 & 1964 & 191 & 1981 & 205 \\
1959 & 187 & $\underline{\mathbf{2 0 1 4}}$ & $\underline{\mathbf{1 8 8}}$ & $\underline{\mathbf{2 0 1 5}}$ & $\underline{\mathbf{1 9 9}}$ \\
\hline
\end{tabular}

As can be seen from Figure 1, in the north of the country a greater frequency have precipitation excess with values between 450 and $700 \mathrm{~mm}$. During the period under review, there were 51 cases with annual rainfall amounts between these 
values. Of these, in eight cases the amounts of rainfall ranged between 434 and 476 $\mathrm{mm}$, and in eight cases between 602 and $644 \mathrm{~mm}$.



Figure 1. The frequency of annual excess rainfall manifestation,

$$
\text { Briceni st. (1950-2015) }
$$

Towards southern region, there is a decrease of annual excess rainfall frequency of over $600 \mathrm{~mm}$, as well those below $500 \mathrm{~mm}$. At Chisinau meteorological station, during the 1950-2015 period there were eight cases with amount of rainfall between 530 and $556 \mathrm{~mm}$, and 9 cases - between 580 and 610 $\mathrm{mm}$ (Figure 2). These two classes of values constitute $26 \%$ in the 66 analyzed years.

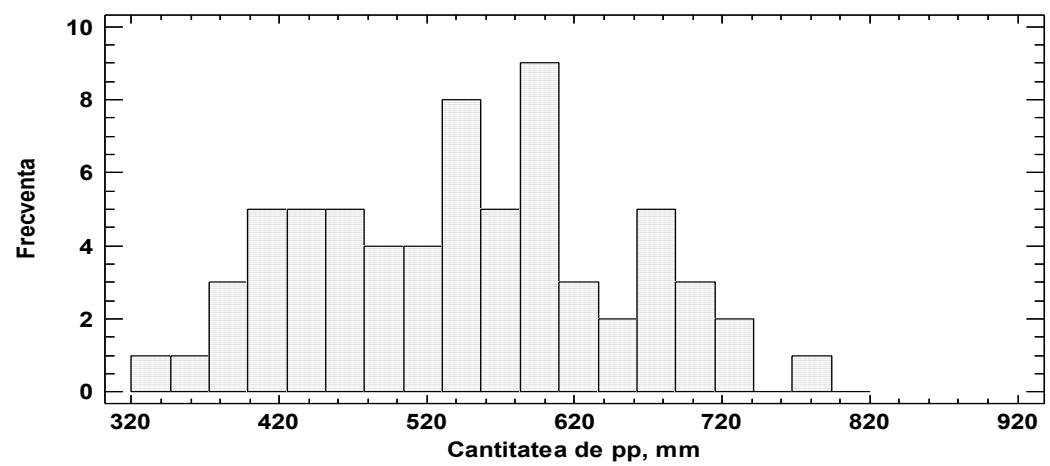

Figure 2. The frequency of annual excess rainfall manifestation. Chișinău st. (1950-2015)

In the southern region of the country in the period 1950-2015, nine years have been reported with rainfall amounts summarized 438 and $470 \mathrm{~mm}$ (Figure 3). In the other 30 cases annual rainfall values were between 500 to $627 \mathrm{~mm}$. Extreme 
values at Cahul meteorological station during the study period were recorded in 2003 - with minimum of $307 \mathrm{~mm}$ and 1966 - with a maximum of $818 \mathrm{~mm}$.



Figure 3. The frequency of annual excess rainfall manifestation.

Cahul st. (1950-2015)

An important feature of the precipitation regime is the maximum quantities of atmospheric precipitation fallen within 24 hours. They have the largest and most direct negative influence in triggering other risks, especially hydrological and geomorphological ones. Maximum amounts of rainfall in 24 hours can reflect the rainfall's instability. It is sometimes possible as the diurnal rainfall to exceed the average monthly amount. Therefore, we believe it is extremely important to know their intensity and frequency of manifestations.



Figure 4. The maximum amounts of diurnal precipitation exceeding the threshold of 50 mm, Briceni st. (1950-2013)

In terms of their origin, in one hand they are linked to intense frontal activity, on the other hand by heat convection that stimulates the development of clouds and rainfall intensification [5]. 
The evolution of diurnal rainfall peaks $\geq 50 \mathrm{~mm}$ (1950-2013) indicate that the north (Figure 4) occurred in 17 cases, in the central part - 15 (Figure 5) and in the south of the country - in 19 cases (Figure 6) being largely explained by the manifestation of atmospheric circulation, including the Mediterranean cyclones.



Figure 5. Daytime maximum rainfall exceeding the threshold of $50 \mathrm{~mm}$, Chișinău st. (1950-2013)

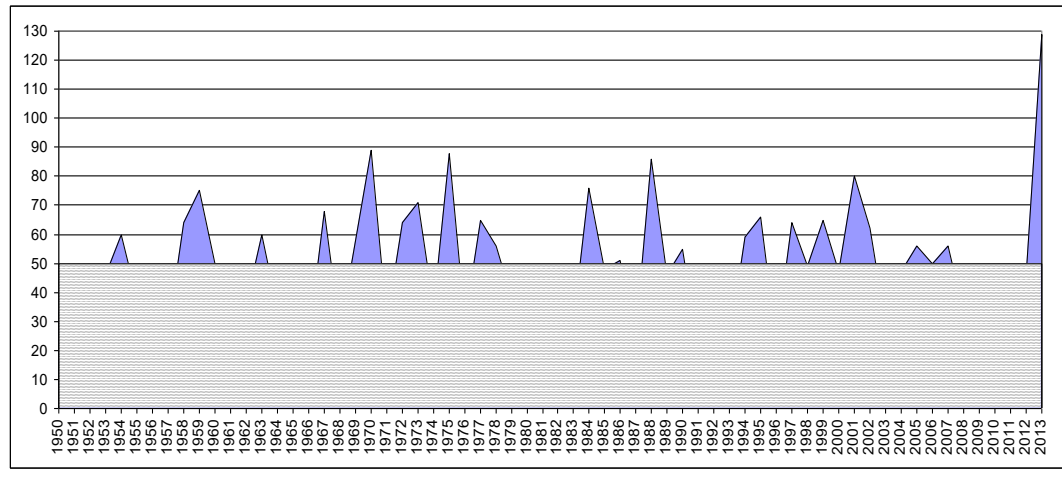

Figure 6. The maximum amounts of diurnal precipitation exceeding the threshold of 50 mm, Cahul st. (1950-2013)

At Chisinau meteorological station, in the last decade, it was reported only one case with daytime maximum amounts of over $50 \mathrm{~mm}$ - in 2005, when the maximum amount of rainfall for 24 hours was $67 \mathrm{~mm}$. While at Briceni and Cahul stations such cases, at the same time were three times - in 2005, 2008 and 2013 at Briceni, with the maximum amount of $101 \mathrm{~mm}$ in 2005, and in the years 2005, 2007 and 2013 - in Cahul, with the maximum amount of $129 \mathrm{~mm}$ in 2013, which is also the absolute maximum for the entire period. 


\section{Conclusions}

Following the analysis of different frequencies of monthly precipitation amounts, it was found a great variability; as according to the synoptic situation, excess rainfall can occur over the whole analyzed perimeter.

In the case of annual maximum rainfall, their mean value decreases from the north (Briceni - $611.8 \mathrm{~mm}$ ) to south (Cahul - $536.6 \mathrm{~mm}$ ), maximum rainfall diurnal the highest average value recorded in south of the country $-49.1 \mathrm{~mm}$, while the average recorded in Chisinau is $45.8 \mathrm{~mm}$, and meteorological station Briceni - 47.4 $\mathrm{mm}$.

The highest value of annual maximum rainfall was recorded at Briceni station - $952.1 \mathrm{~mm}$ in 2010, while the lowest - in Chisinau - $774 \mathrm{~mm}$ in 1966. Also in 1966 there was the absolute maximum at the Cahul meteorological station (818 $\mathrm{mm})$.

Across all analyzed stations the highest frequency values are held within the values classes - 500-600 mm, each station having its peculiarities. So, in the south of the republic is highlighted one more class with a greater frequency, less than $500 \mathrm{~mm}$ ( 437.9 to $469.5 \mathrm{~mm} ; 9$ cases) and in the north, are reported frequencies as high for classes of values from 434.2 to $518.4 \mathrm{~mm}$; 15 cases, but for monthly maximum quantities over $600 \mathrm{~mm}$ (602.6 to $728.9 \mathrm{~mm}$; 22 cases).

In the case of the excess rainfall frequency that reach and exceed the threshold of $50 \mathrm{~mm}$ stands south of the country, where the influence of Mediterranean Cyclones in their retrograde evolution generate long-lasting heavy rainfall, while in winter; particularly heavy snow and mixed precipitation.

\section{References}

Apostol L., Sfîcă L., (2004) Considerații asupra ploilor torențiale în perioada 1992-2002 in Culoarul Siretului, În Lucrările seminarului Geografic „Dimitrie Cantemir”, Nr. 23-24, p. 173-179.

Apăvăloaie M., Pîrvulescu I., Apostol L. (1994) Caracteristici ale cantităților de precipitații atmosferice in 24 ore din Subcarpații Moldovei și Culoarul Siretului. În Lucrările seminarului Geografic „Dimitrie Cantemir”, Nr. 13-14, p. 53-58.

Bogdan O., Marinică I. (2007) Hazarde meteo-climatice: geneză și vulnerabilitate cu aplicații la România. Sibiu: Editura Universității „Lucian Blaga”, 425 p.

Bogdan O., Niculescu E. (1999) Riscurile climatice din România, București: Compania Saga Internațional, $280 \mathrm{p}$.

Dragotă C. (2006) Precipitațiile excedentare în România. București: Editura Academiei Române, 175 p.

Nedealcov M. (2012), Resursele agroclimatice în contextul schimbărilor de climă, Chișinău, 306 p. 